\title{
OLAHRAGA RITMIK DALAM PENATALAKSANAAN PENYAKIT DIABETES MILITUS
}

\author{
Oleh: Paiman \\ Guru Penjasorkes SMPN 5 Wates, Kulon Progo, Yogyakarta
}

\section{Abstrak}

Penyakit diabetes melitus disebabkan oleh terganggunya metabolisme energi karena kurang adekuatnya hormon insulin. Penyebab penyakit diabetes melitus dibagi dua hal, yaitu: (1) jumlah insulin kurang, dan (2) jumlah insulin cukup bahkan berlebih tetapi pintu masuk sel (reseptor) mengalami kerusakan sehingga gula darah tidak dapat masuk ke dalam sel dan hanya menumpuk di dalam darah.

Pengaruh olahraga terhadap penderita penyakit diabetes di antaranya: (1) meningkatkan kualitas kondisi fisik, (2) meningkatkan kemampuan tubuh menahan pertumbuhan virus, (3) meningkatkan efektivitas proses metabolisme organ tubuh, meningkatkan kemampuan adaptasi terhadap histamin, (4) meningkatkan kemampuan jantung, (5) meningkatkan elastisitas pembuluh darah, (6) meningkatkan efektivitas proses respirasi, (7) meningkatkan fungsi ginjal, dan (8) meningkatkan daya serap glukosa langsung ke dalam sel hingga mencapai $40 \%$ tanpa bantuan insulin. Olahraga ritmik sangat baik dilakukan oleh penderita diabetes karena memiliki beberapa keuntungan di antaranya adalah: peralatan sederhana, tidak membutuhkan tempat yang luas, dapat dilakukan di rumah sendiri atau lingkungan sekitar rumah, dapat dilakukan sendirian atau bersama-sama orang lain, aman, dan menyenangkan.

Program latihan olahraga ritmik yang dapat membantu penyembuhan diabetes adalah yang bersifat intermittent. Pengertian intermittent pada bahasan ini adalah berlatih dengan perpaduan latihan anaerobik dan aerobik, yakni: anaerobik selama 1 menit, aerobik 3 menit dengan cara istirahat aktif, 1 menit latihan anaerobik, aerobik 3 menit dengan cara istirahat aktif, demikian seterusnya dilakukan secara berulang-ulang selama kurang lebih 30 menit, dan latihan sekurang-kurangnya dilakukan 3 kali dalam seminggu. Latihan dianggap benar apabila latihan anaerobik 1 menit telah menyebabkan napas terengah-engah. Jika dalam waktu kurang dari 1 menit pelaku telah terengah-engah, latihan anaerobik harus dihentikan, sebaliknya apabila waktu 1 menit telah berlalu tetapi tetap belum terengah maka intensitas latihan harus ditingkatkan.

Kata Kunci: penyakit diabetes melitus, olahraga ritmik, dan penyembuhan. 
Penyakit diabetes melitus (DM) disebabkan oleh terganggunya metabolisme energi karena kurang adekuatnya hormon insulin. Karbohidrat yang terdapat dalam pembuluh darah untuk dapat masuk ke dalam sel tubuh $80 \%$ dibantu oleh hormon insulin dan 20 $\%$ dapat masuk secara langsung. Menurut penyebabnya penyakit diabetes melitus dibagi oleh dua hal, yaitu: (1) jumlah insulin kurang, (2) jumlah insulin cukup bahkan berlebih tetapi pintu masuk sel (reseptor) mengalami kerusakan sehingga gula darah tidak dapat masuk ke dalam sel dan hanya menumpuk di dalam darah.

Kelenjar insulin dapat mengalami kekurangan disebabkan oleh adanya kerusakan pada pankreas yaitu organ tubuh yang bertugas memproduksi kelenjar insulin. Rusaknya pankreas dapat disebabkan oleh beberapa hal antara lain: obat-obatan, makanan, virus, dan pengaruh kimiawi. Penyakit Diabetes yang disebabkan oleh adanya kekurangan insulin akibat rusaknya pankreas ini disebut diabetes tipe I. Penyakit ini biasanya diderita oleh orang yang relatif muda usia.

Penyebab penyakit DM yang lain adalah kelenjar insulin cukup bahkan berlebih dan pankreas keadaannya baik tetapi pintu masuk sel (reseptor) mengalami kerusakan sehingga glukosa tidak dapat masuk ke dalam sel dan hanya berputar-putar mengikuti aliran darah. Hal yang demikian itu menyebabkan lama-kelamaan kadar gula darah semakin tinggi, dan akhirnya menyebabkan komplikasi kerusakan pada organ-organ tubuh yang lain. Penyakit diabetes seperti ini disebut diabetes tipe II. Penyakit DM ini sering diderita oleh orang yang berusia 40 tahun atau lebih. Penyakit tipe II ini banyak disebabkan oleh gaya hidup yang buruk (degeneratif) di antaranya adalah: makan makanan yang tidak berimbang, misalnya: tinggi lemak dan gula tetapi kurang serat, kurang melakukan aktivitas jasmani, banyak stress, dan kurang beristirahat. Kerusakan reseptor sel terutama disebabkan oleh banyak mengkonsumsi lemak jenuh dan kurang makan makanan berserat. Di samping kadar glukosa darah yang tinggi penyakit diabetes juga ditandai dengan Profil lipid yang jelek. Profil lipid tersebut terdiri dari: triglessserid (lemak dari makanan), kolesterol total, HDL (lemak baik), dan LDL (lemak jahat). Profil lipid jelek artinya adalah Triglessserid tinggi, kolesterol total tinggi, HDL (lemak baik) rendah, dan LDL (lemak jahat) tinggi.

Gejala penyakit diabetes ditandai dengan trias poli, yaitu: (1) poliuri, yaitu banyak mengeluarkan air kencing terutama pada malam hari, (2) polidipsi, yaitu banyak minum, dan (3) poliphagi, banyak makan. Banyak mengeluarkan air kencing (poliuri) terjadi karena gula darah banyak terkonsentrasi di pembuluh darah, gula darah kurang dapat sampai ke tempat yang membutuhkannya yaitu sel, akibat dari kurangnya insulin atau rusaknya reseptor sel, maka gula darah hanya berputar-putar mengikuti sirkulasi darah dan akhirnya sampai masuk ke ginjal. Ginjal adalah organ tubuh yang berfungsi menyaring darah, hasil saringannya berupa urine. Karena kadar gula dalam darah sangat tinggi maka urinepun akan mengandung gula dan terasa manis, oleh karena itu sering dikerumuni oleh semut. Banyak minum (polidipsi) disebabkan oleh karena darah mengandung kadar gula yang tinggi, secara kimiawi adanya gula ini akan menyerap cairan yang ada di jaringan sekitarnya. 
Penyerapan cairan dari jaringan sekitar akan berdampak pada kekurangan cairan (dehidrasi). Akibatnya, penderita selalu mengalami rasa haus dan selalu ingin minum. Nafsu makan banyak (poliphagi) terjadi sebagai akibat dari glukosa/gula darah tidak dapat sampai ke dalam sel tubuh sehingga walaupun penderita makan dalam jumlah banyak, namun sel-sel tubuh tersebut tetap saja dalam keadaan lapar. Hal yang demikian itu menyebabkan penderita merasa sering lapar dan ingin selalu makan, padahal sari makanan yang dimakan tidak sampai ke dalam sel hanya berputar-putar di dalam pembuluh darah mengikuti sistem sirkulasi darah. Semakin sering makan, semakin tinggi kadar gula darah. Kadar gula darah yang tinggi dalam pembuluh akan berkibat buruk bagi kesehatan organ tubuh yang lain, misalnya: jantung, ginjal, dan jaringan-jaringan lain.

Gejala-gejala lain penyakit diabetes adalah: (1) pada masa awal tubuh penderita tampak gemuk, namun lama-kelamaan semakin kurus, karena penyakit ini berjalan cukup lama yakni sejak mulai terjangkit sampai menderita sakit kira-kira terjadi dalam kurun waktu 3-4 tahun, (2) keringat lengket, (3) napas berbau alkohol, (4) rasa gatal-gatal di tempat tertentu karena keringat mengandung gula sehingga tumbuh jamur yang menyebabkan rasa gatal tersebut, dan (5) jika kulit terluka sulit untuk disembuhkan. Apabila gejalagejala tersebut diketahui, penderita harus-pandai-pandai mengelola diri agar keadaan tidak semakin parah. Beberapa cara pengelolaan diabetes antara lain: (1) diet tepat, yakni rendah gula dan tinggi serat, (2) melakukan latihan fisik yang kontinu dan terprogram dengan baik, (3) mendapat pengobatan yang baik, dan (4) memperoleh pendidikan/edukasi yang mencukupi tentang seluk-beluk penyakit diabetes melitus.

\section{PENGARUH OLAHRAGA TERHADAP PENDERITA PENYAKIT DIABETES MELITUS}

Para pakar kesehatan olahraga berpendapat bahwa olahraga dapat meningkatkan kualitas kondisi fisik. Menurut Wara Kushartanti (2009) kondisi fisik yang baik, akan dapat meningkatkan kemampuan tubuh menahan pertumbuhan virus, meningkatkan efektivitas proses metabolisme organ tubuh, meningkatkan kemampuan jantung, meningkatkan elastisitas pembuluh darah, meningkatkan efektivitas proses respirasi, meningkatkan fungsi ginjal, dan sebagainya.

Kebugaran jasmani menurut LeMasurier, dkk (2007: 3) adalah kemampuan sistem tubuh untuk bekerja secara bersama-sama secara efisien yang menjadikan sehat dan dapat melakukan aktivitas dalam kehidupan sehari-hari secara efektif. Kemampuan sistem tubuh yang efisien berarti dapat melakukan aktivitas sehari-hari dengan sedikit kehilangan tenaga. Orang yang bugar adalah orang yang dapat melakukan aktivitas sehari-hari tanpa mengalami kelelahan yang berarti, dan masih memiliki cadangan tenaga dan kekuatan untuk dapat menikmati waktu luangnya, serta masih memiliki kemampuan untuk merespons kejadian-kejadian dalam situasi darurat (Suharjana, 2006: 21). 
Olahraga yang dilakukan dalam jangka waktu lama dan teratur terbukti dapat meningkatkan fungsi-fungsi organ tubuh, misalnya: pembuluh darah, jantung, sistem pernafasan, sistem pembuangan, kelenjar endokrin, dan sebagainya. Bagi penderita DM aktivitas berolahraga akan dapat meningkatkan daya serap glukosa langsung ke dalam sel hingga mencapai $40 \%$ tanpa bantuan insulin. Dalam keadaan tidak berolahraga penyerapan glukosa oleh sel $80 \%$ dibantu oleh insulin, dan $20 \%$ masuk secara langsung, tetapi ketika berolahraga persentase yang terserap langsung bertambah menjadi $40 \%$, dan yang melalui bantuan insulin menjadi $60 \%$. Dengan demikian aktivitas olahraga sangat baik dilakukan oleh penderita diabetes untuk menjaga agar organ tubuh dalam keadaan baik.

Menurut Hodder \& Stoughton (2002: 13) pengaruh latihan jasmani terhadap sistem tubuh akan dapat memperbaiki lima tingkat organisasi tubuh di antaranya adalah kimiawi, sel, jaringan, organ, dan sistem. Susunan dan fungsi dari tiap-tiap sistem secara nyata saling berhubungan antara satu dengan yang lainnya dan dirancang untuk memberikan fungsi khusus. Keseimbangan hubungan dari semua sistem ini sangat penting untuk mempertahankan keseimbangan lingkungan internal seperti tetap berfungsinya organ dan melengkapi fungsi-fungsi tubuh.

Kegiatan olahraga yang dilakukan secara teratur dan terukur akan dapat meningkatkan kemampuan tubuh menahan virus/kuman penyakit. Tubuh mempunyai alat penangkal kuman yang disebut sistem kekebalan tubuh. Sistem kekebalan tubuh ini menghasilkan zat penangkal penyakit yang disebut antibodi. Antibodi inilah yang bertanggung jawab terhadap tubuh untuk mengusir musuh-musuh yang tidak dikehendaki, di antaranya adalah: virus, bakteri, toksin, dan benda-benda asing lainnya yang mengganggu kesehatan. Antibodi diproduksi oleh kelenjar limfe yang memanjang ke seluruh tubuh melalui saluran getah bening, dan setiap sendi ada benjolan besar (nodus limfeticus) sebagai terminal kelenjar getah bening ini yang berfungsi membantu memproduksi antibodi yang dibutuhkan oleh tubuh. Kegiatan olahraga misalnya gerakan menekuk dan meluruskan sendi dapat disamakan dengan kegiatan menekan dan melonggarkan aliran enzim getah bening/antibodi. Keadaan tertekan-longgar, tertekan-longgar, yang dilakukan berulang-ulang seperti kegiatan memompa. Kegiatan seperti ini dapat memicu produksi antibodi yang lebih banyak, sehingga apabila tubuh kemasukan kuman/virus maka di dalamnya telah tersedia cukup banyak antibodi yang berfungsi mengusir bibit penyakit, sehingga tubuh tidak mudah jatuh sakit.

Kegiatan olahraga dengan banyak melakukan gerakan menjepit-longgar, menjepitlonggar berulang-ulang pada otot (musculus) dan sendi (articulasio) akan membantu memompa darah untuk kembali ke jantung. Darah yang dipompa oleh jantung akan beredar ke seluruh tubuh. Fungsi darah di antaranya adalah untuk mengangkut O2 dan nutrisi yang dibutuhkan oleh tubuh, serta menggangkut sisa-sisa metabolisme yang tidak berguna untuk dikeluarkan dari dalam tubuh. Sisa-sisa metabolisme tersebut misalnya: berupa 
CO2, sisa obat, racun, dan zat-zat lain yang tidak berguna. Dengan sistem peredaran darah (sirkulasi) yang lancar, maka O2 dan nutrisi yang dibutuhkan oleh sel tubuh akan terpenuhi secara baik. Hal ini akan berpengaruh positif terhadap fungsi sel tubuh. Jika sel ini digambarkan seperti manusia, maka manusia yang berkecukupan makanan akan dapat bekerja lebih giat, sebaliknya apabila kekurangan makanan maka akan loyo, malas, dan tidak produktif. Demikian juga sel apabila kekurangan nutrisi yang dibutuhkan maka tidak akan dapat bekerja secara maksimal.

Pada kasus penderita diabetes dengan kerusakan yang terjadi pada pankreas akibat makanan, toksin, kimiawi, dan sebagainya, perlu adanya proses pembangunan kembali organ tersebut agar kembali menjadi sehat. Gizi makanan yang dibutuhkan untuk membangun/membentuk kembali sel-sel baru yang telah rusak adalah protein. Protein dihasilkan dari bahan makanan lewat proses pencernaan. Zat protein untuk dapat bergerak dari organ pencernaan menuju sel yang rusak perlu diangkut oleh darah. Dengan demikian semakin lancar aliran darah sebagai akibat dari aktivitas berolahraga akan dapat membantu mempercepat pemulihan sel yang rusak di pankreas.

Saat berolahraga tubuh membutuhkan tambahan energi untuk menyuplai kebutuhan otot yang sedang berkontraksi. Untuk menambah energi dibutuhkan proses oksidasi/ pembakaran. Salah satu hasil pembakaran adalah panas tubuh. Saat berolahraga tubuh akan mengalami kenaikan suhu beberapa derajat di atas suhu tubuh normal. Pada saat tidak beraktivitas tinggi suhu tubuh normal manusia adalah 36-37 derajat celsius, namun ketika berolahraga suhu tubuh dapat naik menjadi 40 derajat atau lebih. Kenaikan suhu tubuh ini akan bermanfaat bagi penderita diabetes untuk membantu mengeluarkan sisasisa makanan, obat, racun, dan sebagainya yang tidak bermanfaat bersama keluarnya keringat dari dalam tubuh. Demikian juga saat berolahraga maka tubuh akan mengeluarkan cadangan darah yang tersimpan di hati untuk ikut bersama-sama dipompa mengalir ke seluruh tubuh sehingga transportasi $\mathrm{O} 2$ dan nutrisi akan dapat berjalan lebih efektif.

Menurut Bucher (1983: 313-318) pengaruh olahraga terhadap tubuh adalah: (1) meningkatkan kesehatan secara umum dan otot jantung, (2) meningkatkan volume darah, (3) meningkatkan volume darah yang dipompa ke jantung (stroke volume), memperbaiki tekanan darah, (4) memperbaiki keadaan darah, (5) memperbaiki sel darah merah, (6) memperbaiki respirasi, (7) memperbaiki sistem otot (muscular), (8) memperbaiki sistem pencernaan dan pembuangan, (9) memperbaiki sistem endokrin, (10) mempertahankan suhu tubuh, dan (11) memperbaiki sistem syaraf. Dengan perbaikan proses metabolisme ini maka dapat membantu pengelolaan penyakit DM.

\section{OLAHRAGA RITMIK}

Olahraga ritmik berasal dari gabungan dua istilah yaitu olahraga (sport), dan ritmik/ irama. Menurut Sukintaka (1999: 20), pengertian olahraga yaitu aktivitas jasmani dan permainan yang dilakukan dengan perjuangan melawan dirinya sendiri, teman bermain, 
dan lingkungan alam untuk mencapai kemenangan. Di sisi lain, ritme/irama berarti suatu bunyi/aktivitas yang terjadi berulang-ulang secara teratur dan kontinyu dalam kurun waktu tertentu. Dari perspektif seni musik, Setyo Budi dkk (2006: 68) menyatakan mengenai irama adalah ketukan yang konsisten dan berulang dengan pola tertentu. Pengertian olahraga ritmik pada tulisan ini adalah aktivitas gerak manusia yang sengaja dilakukan dengan mengikuti irama terentu, yang berlangsung dalam kurun waktu tertentu. Berdasarkan pengertian ini maka setiap gerak-gerak manusia yang sengaja dilakukan mengikuti irama tertentu termasuk dalam kategori aktivitas ritmik. Misalnya mengerakgerakan ujung kaki, jempol tangan, mengangguk-angguk mengikuti lagu sudah termasuk dalam kategori aktivitas ritmik, namun tidak semua aktivitas ritmik termasuk kategori aktivitas olahraga.

Aktivitas ritmik yang termasuk olahraga harus memenuhi beberapa kriteria di antaranya adalah: (1) adanya perjuangan mengalahkan diri sendiri, lawan, atau alam lingkungan, (2) adanya peningkatan intensitas kerja jantung dan paru-paru, dan (3) adanya peningkatan kualitas kondisi jasmani. Dari tiga kriteria di atas yang paling menonjol adalah adanya peningkatan intensitas kerja jantung dan paru-paru. Dengan adanya peningkatan intensitas kerja jantung dan paru-paru pada ambang tertentu akan dapat meningkatkan kualitas kondisi fisik. Menurut Sukadiyanto (2005: 24) intensitas latihan dapat ditunjukkan dengan ulangan maksimal (repetition maximum), denyut jantung per menit, kecepatan, jarak tempuh/lama waktu, jumlah ulangan perwaktu tertentu, dan interval. Pada olahraga ritmik intensitas latihan sangat dipengaruhi oleh kecepatan irama, kesungguhan gerak, dan lama waktu latihan.

Olahraga ritmik sangat baik dilakukan oleh penderita penyakit DM, karena memiliki beberapa keuntungan di antaranya adalah: peralatan sederhana, tidak membutuhkan tempat yang luas, dapat dilakukan di rumah sendiri atau lingkungan sekitar rumah, dapat dilakukan sendirian atau bersama-sama orang lain, aman, dan menyenangkan. Lebih dari itu, karena perasaan canggung dan rasa malu dilihat orang, olahraga ini dapat dilakukan di dalam kamar dengan memutarkan lagu lalu bergerak mengikuti irama. Apabila gerakan telah mengikuti ketentuan walaupun dilaksanakan di dalam kamar sendiri tidak akan mengurangi kemanfaatannya bagi penderita.

Olahraga ritmik yang dilakukan masyarakat banyak macamnya, di antaranya adalah: gerak lagu, senam poco-poco, senam kesegaran jasmani, senam aerobik, let dance, dan sebagainya. Ciri utama dari olahraga ritmik adalah adanya musik sebagai alat bantu bergerak. Musik dalam olahraga ritmik banyak manfaatnya di antaranya adalah: (1) merangsang seseorang untuk bergerak lebih serius, (2) membantu memudahkan mengingat bentuk gerakan dan urutan gerakan, dan (3) menambah rasa senang sehingga tidak lekas merasa lelah. Besar pengaruh musik terhadap intensitas gerak pesenam, misalnya irama yang lembut/pelan menyebabkan bergerak pelan, sebaliknya irama cepat dan menghentak 
berpengaruh terhadap kecepatan gerak dan kesungguhan. Oleh karena itu untuk melakukan olahraga ritmik ini dibutuhkan kepandaian memilih jenis musik dan irama. Perlu dipilih musik dengan beat yang jelas, misalnya birama $2 / 4,4 / 4,6 / 8$, dan $8 / 8$, serta memiliki tempo yang konsisten agar mudah diikuti gerakannya. Musik yang sering berubahubah temponya akan sulit untuk diikuti, hal yang demikian akan berdampak pada hilangnya kontinuitas gerakan. Hilangnya kontinuitas gerak akan berakibat kehilangan kenikmatan bergerak dan intensitas gerak sehingga kebugaran jasmani yang diinginkan sulit tercapai.

Musik yang temponya sering mengalami perubahan apabila digunakan untuk mengiringi senam massal akan merusak kekompakan, karena setiap orang memiliki kepekaan terhadap musik berbeda-beda. Hilangnya kekompakan akan berdampak pada menurunya intensitas gerak, estetika gerak, dan dapat menghilangkan kepercayaan diri. Hilangnya kepercayaan diri dapat menyebabkan seseorang terutama bagi pemula enggan bergerak, sehingga tujuan berolahraga untuk peningkatan kualitas kondisi fisik tidak dapat tercapai.

Selain jenis musik yang digunakan, hal lain yang perlu dipertimbangkan apabila olahraga ritmik ini dilakukan secara massal di klub atau perkumpulan adalah pakaian dan tempat latihan. Ada sebagian orang tertarik terhadap olahraga senam aerobik dimulai dengan memiliki ketértarikan terhadap pakaian yang dipakai oleh para peraga. Pakaian yang dipakai dalam olahraga ritmik sebaiknya berbahan lentur/elastis sehingga tidak menganggu gerakan dan tidak menghambat jalan darah, menyerap keringat, pakaian menarik dari segi rancangan dan warna, serta menambah rasa percaya diri, misalnya pemakai merasa tambah seksi, merasa tambah langsing, dan sebagainya. Tempat berlatih juga harus mendapat perhatian agar tidak terkesan murahan. Tempat latihan harus dibuat yang representatif, misalnya: memiliki fasilitas sound sistem yang memadahi, dikelilingi cermin agar peserta dapat mengoreksi gerakannya sendiri, serta dapat mengamati perubahan yang terjadi pada dirinya sendiri setelah aktif mengikuti olahraga senam ritmik dalam kurun waktu tertentu. Beberapa teknik dasar senam ritmik terdapat pada tabel 1 dan tabel 2. 
Tabel 1. Teknik Dasar Gerak Kaki (basic movement foot)

\begin{tabular}{|c|l|l|}
\hline No & \multicolumn{1}{|c|}{ Jenis } & \multicolumn{1}{c|}{ Teknik } \\
\hline 1 & a. Gerak di tempat & 1) jalan di tempat (walk) \\
& & 2) menyentuhkan ujung kaki (thoe touch) \\
3) menyentuhkan tumit kaki (heel touch)
\end{tabular}


Tabel 2. Teknik Dasar Gerak Lengan (Basic Movement Arm)

\begin{tabular}{|c|c|c|}
\hline No & Jenis & Teknik \\
\hline 1 & a. Gerak bersama-sama & $\begin{array}{l}\text { 1) mendorong arah depan, samping, atas (push). } \\
\text { 2) menarik arah belakang, bawah, tengah (pull). } \\
\text { 3) ayun arah depan-belakang, samping-rapat, samping- } \\
\text { samping (swing) } \\
\text { 4) memutar arah depan, belakang, samping (rotasi). } \\
\text { 5) meninju (boxing) } \\
\text { 6) meniru gerakan pada olahraga yang lain (adoptive) } \\
\text { 7) menekuk siku ( } \text { hand curl). } \\
\text { 8) meluruskan siku ( } \text { tricep extention). } \\
\text { 9) gerak memompa (pump). } \\
\text { 10) gerak kupu-kupu (buterfly). }\end{array}$ \\
\hline & b. Bergantian & $\begin{array}{l}\text { 1) mendorong arah depan, samping, atas (push). } \\
\text { 2) menarik arah belakang, bawah, tengah (pull). } \\
\text { 3) ayun arah depan-belakang, samping-rapat, samping- } \\
\text { samping (swing) } \\
\text { 4) memutar arah depan, belakang, samping (rotasi). } \\
\text { 5) meninju (boxing) } \\
\text { 6) meniru gerakan pada olahraga yang lain (adoptive), } \\
\text { misal gerakan silat, berbaris, menembak, dan } \\
\text { sebagainya. } \\
\text { 7) menekuk siku (hand curl). } \\
\text { 8) meluruskan siku ( } \text { tricep extention). } \\
\text { 9) gerak memompa (pump). } \\
\text { 10) gerak kupu-kupu (buterfly). }\end{array}$ \\
\hline
\end{tabular}

Dikutip dari Abdullah (2007)

\section{PENYUSUNAN PROGRAM LATIHAN OLAHRAGA RITMIK UNTUK PENYEMBUHAN PENYAKIT DIABETES MELITUS}

Olahraga ritmik dapat digunakan sebagai sarana membantu penyembuhan penyakit DM, apabila dilakukan sesuai dengan program latihan yang tepat dan sesuai dengan karakteristik penyakit DM. Apabila program olahraga ritmik yang dilakukan seseorang tidak tepat kemungkinan yang terjadi ada tiga hal, yaitu: (1) dapat membantu penyembuhan, (2) atau sebaliknya justru memperparah keadaan, dan (3) atau tidak berdampak apa pun. 
Program latihan olahraga ritmik yang dapat membantu penyembuhan harus bersifat intermitent. Pengertian intermitent adalah berlatih dengan perpaduan antara latihan anaerobik dan aerobik, yakni: anaerobik selama 1 menit, aerobik 3 menit dengan cara istirahat aktif, 1 menit latihan anaerobik, aerobik 3 menit dengan cara istirahat aktif, dan demikian seterusnya latihan dilakukan berulang-ulang selama kurang lebih 30 menit. Latihan dianggap benar apabila latihan anaerobik 1 menit telah menyebabkan napas terengahengah. Apabila latihan 1 menit belum menyebabkan napas terengah-engah berarti intensitas latihan harus ditingkatkan. Sebaliknya, bagi penderita yang sudah cukup parah belum sampai 1 menit telah terengah-engah latihan harus dihentikan dilanjutkan dengan istirahat aktif 3 menit, demikian seterusnya. Latihan dilakukan selama kurang lebih 30 menit dan dilakukan sekurang-kurangnya 3 kali dalam seminggu.

Latihan anaerobik ini mempunyai beberapa tujuan di antaranya adalah untuk menguras glikogen dalam sel tubuh. Sel tubuh yang terkuras energinya akan dapat menyerap energi lebih banyak dibandingkan dengan yang tidak terkuras. Hal ini dapat digambarkan seperti seseorang yang sedang berpuasa, ketika datang waktu berbuka seakan-akan ingin minum dan makan yang sebanyak-banyaknya. Demikian juga sel yang terkuras energinya akan dapat menyerap glukosa lebih banyak, hingga $20 \%$ dari keadaan biasa. Latihan istirahat aktif selama 3 menit bertujuan untuk memetabolisir lemak sehingga pintu sel (reseptor) lebih mudah dilalui oleh glukosa untuk dapat masuk ke dalam sel.

Istilah aerobik dan anaerobik sebenarnya mengacu pada sistem energi yang dibutuhkan oleh tubuh saat beraktivitas. Menurut Bompa (1999: 20-21) yang dimaksud dengan sistem anaerobik adalah penggunaan energi otot yang berasal dari ATP-CP, phosphagen, lactic acid yang terjadi kira-kira mencapai waktu 70 detik, waktu 70 detik sampai 120 detik (2 menit) merupakan waktu perpindahan dari sistem anaerobik menuju sistem aerobik, dan lebih dari 2 menit masuk era aerobik. Yang dimaksud sistem aerobik adalah aktivitas olahraga yang telah melewati waktu lebih dari 2 menit, dan sistem energi yang digunakan adalah melalui oksidasi glikogen dengan bantuan O2. Waktu yang dibutuhkan adalah 25 menit hingga 2 jam. Sistem energi yang digunakan adalah melalui pembakaran lemak, dan jika lebih dari 2 jam melalui pembakaran protein. 
Tabel. 3 Contoh Program Latihan Olahraga Ritmik pada DM.

\begin{tabular}{|c|c|c|c|c|}
\hline \multicolumn{5}{|c|}{ PEMANASAN (5-10 menit) = Gerak lambat ditekankan pada penguluran } \\
\hline \multirow{3}{*}{$\begin{array}{l}\text { INTI } \\
4 \text { Menit } \\
\text { Pertama }\end{array}$} & \multicolumn{3}{|c|}{ Anaerobik 1 menit } & \multirow[t]{2}{*}{ Istirahat aktif 3 menit } \\
\hline & Kaki & Tangan & Irama & \\
\hline & $\begin{array}{l}\text { Walk } \\
\text { kick }\end{array}$ & $\begin{array}{l}\text { Push } \\
\text { buterfly }\end{array}$ & $\begin{array}{l}2 / 4 \\
2 / 4\end{array}$ & Berdiri \& gerak santai $8 / 8$ \\
\hline \multirow{3}{*}{$\begin{array}{l}4 \text { Menit } \\
\text { Kedua }\end{array}$} & \multicolumn{3}{|c|}{ Anaerobik 1 menit } & Istirahat aktif 3 menit \\
\hline & Kaki & Tangan & Irama & \\
\hline & $\begin{array}{l}\text { Kick } \\
\text { Single step }\end{array}$ & $\begin{array}{l}\text { Pull } \\
\text { buterfly }\end{array}$ & $2 / 4$ & Berdiri \& gerak santai $8 / 8$ \\
\hline \multirow{3}{*}{$\begin{array}{l}4 \text { Menit } \\
\text { Ketiga }\end{array}$} & \multicolumn{3}{|c|}{ Anaerobik 1 menit } & Istirahat aktif 3 menit \\
\hline & Kaki & Tangan & Irama & \\
\hline & $\begin{array}{l}\text { Knee up } \\
\text { kick }\end{array}$ & $\begin{array}{l}\text { Buterfly } \\
\text { Boxing }\end{array}$ & $2 / 4$ & Berdiri \& gerak santai $8 / 8$ \\
\hline \multirow{3}{*}{$\begin{array}{l}4 \text { Menit } \\
\text { Keempat }\end{array}$} & \multicolumn{3}{|l|}{ Kaki } & Istirahat aktif 3 menit \\
\hline & kaki & Ta ngan & irama & \\
\hline & $\begin{array}{l}\text { Knee up } \\
\text { Double step }\end{array}$ & $\begin{array}{l}\text { Swing } \\
\text { push }\end{array}$ & $2 / 4$ & Berdiri \& gerak santai $8 / 8$ \\
\hline \multirow{4}{*}{$\begin{array}{l}4 \text { Menit } \\
\text { Kelima }\end{array}$} & \multicolumn{3}{|c|}{ Anaerobik 1 menit } & Istirahat aktif 3 menit \\
\hline & Kaki & Tangan & Irama & \\
\hline & $\begin{array}{l}\text { Kick } \\
\text { Knee up }\end{array}$ & $\begin{array}{l}\text { Tricep } \\
\text { extention } \\
\text { buterfly }\end{array}$ & $2 / 4$ & \\
\hline & $\begin{array}{l}\text { Kick } \\
\text { Knee up }\end{array}$ & \begin{tabular}{|l|} 
Tricep \\
extention \\
buterfly \\
\end{tabular} & $2 / 4$ & Berdiri \& gerak santai $8 / 8$ \\
\hline PENDINGI & \multicolumn{4}{|c|}{$(5-10$ menit) $=$ Gerak lambat ditekankan pada penguluran } \\
\hline
\end{tabular}




\section{KESIMPULAN}

Penyakit DM disebabkan oleh terganggunya metabolisme energi karena kurang adekuatnya hormon insulin. Gejala penyakit diabetes ditandai dengan trias poli, yaitu: (1) poliuri, yaitu banyak mengeluarkan air kencing terutama pada malam hari, (2) polidipsi, yaitu banyak minum, dan (3) poliphagi, banyak makan.

Aktivitas olahraga dalam jangka waktu lama dan teratur dapat meningkatkan daya serap glukosa langsung ke dalam sel. Salah satu olahraga yang baik bagi penderita DM adalah olahraga ritmik, yaitu olahraga yang dilakukan menurut irama tertentu, seperti gerak dan lagu, senam poco-poco, senam aerobik dan yang sejenis.

\section{DAFTAR PUSTAKA}

Abdullah. (2007). "Aktivitas Ritmik", Makalah disajikan dalam fasilitasi KTSP Guru Penjasorkes SeIndonesia di PPPPTK PenjasBK. Jakarta: tidak diterbitkan.

Bucher, C.A. (1983). Foundations Of Physical Education \& Sport, Ninth Edition. USA: The C.V. Mosby Company.

Bompa, T.O. (1999). Periodization: Theory and Methodology of Training. $4^{\text {th }}$ Edition. Champaign, IL: Human Kinetics.

Corbin, C.B., \& Lindsey. (2007). Fitness For Life Middle School Teacher's Guide, fifth edition. Champaign, IL: Human Kinetics.

Hoffman, Matthew., \& LeGro, William. (1993). Disease free How to Prevent, Treat and Cure More Than 150 Illnesses and Conditions, Terjemahan T. Hermaya. Jakarta: PT Gramedia.

Hodder \& Stoughton.( 2002). Sports Therapy An Introduction to Theory and Practice. London: Great Britain For Hodder \& Stoughton Educational.

Suharjana. (2006). Kebugaran Jasmani. Modul Kuliah Untuk Mahasiswa S1. Yogyakarta. FIK UNY

Sukadiyanto. (2005). Pengantar Teori dan Metodologi Melatih Fisik. Yogyakarta: FIK UNY. Setyo Budi, dkk. (2006). Seni Budaya untuk SMP Kelas VII. Jakarta: Erlangga.

Wara Kushartanti.( 2009). Terapi Olahraga, Program Pasca Sarjana UNY, Prodi Ilmu Keolabragaan. Yogyakarta: tidak diterbitkan. 